\title{
PoLAR: Political and Legal Anthropology Review
}

Book Reviews

The Social Life of Security

September I6, 2019 Comments closed

by Lori Allen, SOAS University of London

- Spaces of Security: Ethnographies of Securityscapes, Surveillance, and Control, Setha Low and Mark Maguire, eds. (New York: New York University Press, 20I9).

- From Righteousness to Far Right: An Anthropological Rethinking of Critical Security Studies, by Emma McCluskey (Montreal \& Kingston: McGill-Queen's University Press, 2019).

- Nightmarch: Among India's Revolutionary Guerrillas, by Alpa Shah (London: Hurst \& Company, 2018).

- Fear, Space and Urban Planning: A Critical Perspective from Southern Europe, by Simone Tulumello (Springer International Publishing Switzerland, 20I7).

Securitization now shapes almost every dimension of most people's lives, affecting everything from football matches to refugee reception, urban planning to outer space.

And, of course, airports.

A recent experience I had while traveling back to London gave me a particularly affectladen insight into anthropologists' burgeoning interest in security regimes. It gave me a 
sense of how overwhelming the emotions that are a constituent part of securitization can be. It also highlighted how important it is that ethnographers not stop at investigating affect alone, but push beyond to understand the material and structural dynamics that are also driving the security-saturation of the globe these days.

I had set off the alarm in the metal detector at a Sicilian airport. "It must be that mysterious area of my right ankle that inexplicably shows up on screens across the globe's airport security systems," I thought. As predicted, I was asked to step aside to be frisked by a female security guard. After the typical pat down, the guard spoke rapidly to me in Italian, the only word of which I recognized was "telephone." I responded in mute confusion, and she repeated herself with greater volume and insistence. The combination of peeved security guard, loud volume, and travel anxiety tripped me into some traumatic back flip, returning me psychically to my days of fieldwork in Palestine and the hourslong interrogations by Israeli security personnel at Ben Gurion Airport that became my routine when traveling to renew my visa every three months. (A more invasive process continues to be the difficult and sometimes seriously traumatizing routine for many.) The accusatory hostility from the Israelis, and the knowledge of my physical powerlessness that permeated those passages through Tel Aviv has, it turns out, left an indelible mark. When the Italian security guard said something like "telephone" again, I started reciting my telephone number, wondering vaguely, as I started to dissociate into the fog of my skyrocketing anxiety, if this was an Italian way of checking passenger identity. Just as the lightning of my fantasy lit upon the question of what kind of database the Italians shared with UK telecom companies, the guard realized what I was doing. She laughed uncomfortably - and at me-while making a gesture that finally helped me understand that she wanted to see my cell phone. As I fished the phone out of my bag, the guard commented to her colleague in words I could not understand but with a tone of mockery that was clear. I stammered excuses at her as she inspected the phone-for what, really?and I wondered both why I was so embarrassed by my misunderstanding and when my heart might return to its normal pace.

In my bout of (perhaps mildly post-traumatic) paranoia, I had given more power to the Italian guard than she wanted. In overstretching to submit myself to her search, I became a suspicious character. Or at least that's how I felt. I reassembled my dignity along with my personal belongings, and as nonchalantly but quickly as I could shuffled through the 
queue with the other, merrier holiday-goers.

All in all, a mild encounter with the contemporary security regime. Especially in comparison to the violent and life-changing experiences that many less privileged, and less white, people go through at Israeli and other international borders (ACLU n.d, Crivelente 20I6, B'Tselem 2017). This was an experience in which the sense of threat and discomfort was mostly self-inflicted. But it was an encounter that conveys something of what ethnographers of such security regimes are also grappling with: the experiential dimensions of life in an increasingly securitized world and the emotional contortions and paranoia that security apparatuses provoke; the hubris of state agents; how people live with the sense of insecurity that pervades everyday life; and the fracturing of social relations that is often produced in that miasma of uncertainty.

More observational than explanatory, the four books reviewed here show some of the many ways the security obsession and paranoia manifests itself, determining how people live in their bunkered houses everywhere from Israel and New York to Johannesburg. These texts analyze dynamics that are both deeply shaped by their local contexts and histories, and cannot be understood without an appreciation of the parastatal, transnational movements of people and ideas that have congealed into a veritable mania for security today. Only by reading across these distinctive texts and geographies can one grasp how deeply interconnected the trends and technologies of securitization have become, as they have militarized police forces, bulked up private security companies, and pried private spaces open to surveillance.

Although none of these authors make the argument explicitly, their studies suggest that a convergence of interests that are largely Islamophobic, anti-immigrant, and anti-poor propels this security overload (in addition to the financial interests of private security companies and militaries seeking to inflate their budgets). The xenophobia and racism of the nation-state system has congealed in such a way to make the "War on Terror" and the "refugee crisis" pretext enough for state security agents in Mombasa to put up posters demanding information on suspects "wanted dead or alive" (Gluck 2019, 40), and for India to incarcerate thousands without trial (Shah 2018, 246). The same rationalizations open public coffers, prompting the government to spend $£ 5$ million to augment the "ring of steel" around London's financial district (BBC 20I6),[i] and justify the installation of 
hundreds of CCTVs and security guards to make every football match in Rio entertainment-camera ready (Rial 2019, IOI). The repression and exclusion of immigrants and other stigmatized populations (like the Roma in Italy) is a justification and goal of the "security emergency" (Tulumello 2017, 2, 33, 48-49).

These books represent a new phase in critical security studies (CSS), a field which has hitherto been largely dominated by international relations scholars. It has a distinguished history of producing "schools" and "collectives" [ii] that have been critical of traditional approaches to understanding security as only a matter of state policy. In this new iteration of CSS, there are resonances with the post-positivist, social constructivist approach of the Copenhagen School, which understood security as a self-referential issue: something becomes a matter of security if constructed as such. Similarly, much anthropology of security seeks to uncover the ideological justifications and uses of securitization by tracing how an issue comes to be defined and treated as a security problem. This work also parallels some impulses of the Aberystwyth School of CSS, which sought to upend the scales of traditional thinking and put the security of the disenfranchised at the center of their critical project. Anthropologists, often interested in recording experiences of insecurity, collect data that could feed in to a broader project of this kind, while challenging the methodological Whiteness that some argue remains at the heart of the CSS project (Howell and Richter-Montpetit 2019).[iii] Most recently, inspired by

postcolonial international relations studies and moves to decolonize knowledge across the Global South, "The Beirut Security Studies Collective," which includes anthropologists, has come together as an effort to develop a critical security studies approach to global politics with a focus on and from the Middle East and North Africa. It is by combining the lessons, methodologies, and critiques by (and about) these various strands of work that ethnographic approaches by anthropologists and others might offer a uniquely critical purchase on the novel conditions of security today.

This recent surge in the anthropology of security tends to explore particular aspects of the security machinery: the media's ideological framing of risks to create fear of enemies and criminals; a public discourse that fuels this fear while converting senses of insecurity into demands for surveillance technology; architectural innovations that divide and protect an "us" and exclude the "them." What is required of an anthropological approach to critical security studies now is to put these pieces of the picture together and identify who is 
benefiting, and to find the chinks in the system where resistance is possible. Melding anthropological concern for the lived experience of insecurity and everyday security with a return to the critical and distinctively emancipatory impulse of some work in the first generation of critical security studies (Hynek and Chandler 2013) could move the field forward in ways that might help us imagine, and one day instantiate, an alternative world.

\section{Communism Marching against Capitalism in India}

Although each of these four books takes a very different methodological and conceptual approach to the question of security, they are all grounded in ethnographic engagement with the people and contexts they analyze, and each offers some kind of theoretical and political critique of our world's inundation with security. The most successful across all these facets is Alpa Shah's Nightmarch (2018). An anthropologist with many years of experience studying and living with the Naxalite communist movement in northeastern India, Shah has delivered a grippingly readable "creative nonfiction" account of her walk across the Jharkhand hills with a guerrilla troop of Naxalite rebels.

Shah introduces us to a range of people included among the mostly poor Adivasis-a marginalized and exploited minority of India-who are the foot soldiers of this Maoist revolutionary movement. She depicts numerous incidents that help the reader understand why so many people continue to join this movement, still after more than half a century and despite the Indian government's unspeakably harsh attempts to quash it. Both abstract ideals like tribal autonomy and "a vision for a different equal world" (Shah 2018, I02) as well as more mundane and personal desires (I24-26) push the fewer than Io,00o armed members (33) to take part in this collective fight for labor and land rights. In contrast to the claims of "security experts," Shah notes, people choose to join the guerrillas not because they are coerced but because, for example, the Naxalites provide essential services or higher wages (135, I72-75). Even more than material support, in Shah's estimation, "the much deeper appeal of the Naxalites was the respect and dignity with which they treated the Adivasis, looking upon them as equal human beings" (I36).

At the center of the story are Prashant, Shah's polite and helpful minder-guide across her 250-kilometer journey, and Gyanji, a senior Maoist leader with whom Shah had the occasional political debate about the patriarchy that still besets the movement. Not a 
romanticizing paean to communism, also peopling the story are more dubious characters like Vikas, whose loyalties and motivations were rather less idealistic and more materialistic than those of his comrades. As we come to know these and others, one of the book's real theoretical contributions-which is at the same time a methodological onebecomes apparent. Shah shows how ethnographic sensitivity to the very personal stories, histories, and motivations of regular folks can help us understand why people would risk their lives, how they could go up against a brutal Indian security state in their seemingly utopian fight to hew an egalitarian, "casteless and classless" (94) future out of the present "farce" that is Indian democracy (83). Gyanji's education and experience as a human rights worker, writing about the atrocities-the rapes, beatings, exploitation-against low-caste laborers committed by high-caste landlords; Kohli's wish to escape a stressful family, abusive school, and avoid a future as a tea-shack proprietor; Lila's wish for the exciting life of a guerrilla-all of these reasons tumble into the mix that make up the energies of a political movement that offers "a sanctuary for society's misfits" (I37).

In drawing these human pictures, Shah also conveys what drives the relentlessness of the counter-insurgency efforts against the Naxalites. If the revolutionary egalitarianism of the Maoists was not threatening enough, there are also resources at stake, leading to the Indian state's complicity with mining companies in "one of the greatest people-clearing operations of our times" (xvii). The state seeks to sweep out and encircle the Adivasi areas (propagandized as nests of red-terror) because they are rich in coal and minerals (244-45). Although Nightmarch offers a compelling narrative, the political economy of these dramas is also subtly but clearly explained throughout, helping us understand the struggle for dignity that the Naxalite are pursuing against the avarice of Indian business. Adivasi and other rights activists continue to work to ensure that local people are part of decisionmaking processes in areas affected by mining projects. That India's principal counterterrorism law, the Unlawful Activities (Prevention) Act, is applied in politically and economically motivated ways against these activists makes clear whose security really matters to the Indian state (Human Rights Watch 2018).

Shah's book stands out in two important ways. One is its attention to the economic interests behind securitization processes and activities - in this case the maintenance of a class and caste hierarchy for the benefit of the elite, and the extraction of wealth from indigenous land and labor. Second is its gritty focus on the lives of people refusing to 
succumb to a security regime. In contrast, what concerns some work in critical security studies, including the other books under review here, is the success of security regimes: how the security discourse and imagination infiltrates and interpellates ever-broader swathes of people. With this focus on how threats are constructed, defined, mobilized, and made effective, important questions of who securitization benefits, who is propelling these dynamics, why so many people buy into the fear-mongering hype even when it harms them, and how some resist it, go unasked.

\section{Everyday InSECURITIZATION IN SWEDEN}

In its eagerness to take an anthropological approach to the workings of security logics and what she calls "every day (in)securitzation processes," Emma McCluskey's From

Righteousness to Far Right (2019, II) suffers from some of this weakness in anthropologically-inclined critical security scholarship that does not ask who and what is driving these processes. An International Relations scholar who has engaged ethnography as her primary method, McCluskey hones in on what she calls "micropractices" and "microphysics" - the everyday life that is the traditional stock and trade of anthropologists -to describe the shifts in attitude among Swedish villagers whose initially warm welcome of Syrian refugees dissolved into bitter suspiciousness and hostility. The book opens up important questions about how fear of the outsider manifests in local ways. In trying to convince traditional IR or political science scholars to pay attention to non-elite, nonstate dimensions of security, to "destabiliz[e] political science's focus on speech acts and the spokesperson" (I70), McCluskey picked up anthropologist's tools to engage regular people and the quotidian. The results of her efforts are mixed.

The book does a fine job of setting the scene and explaining the stakes of a study focused on a little village in Sweden. This is a country built partly on a national myth of moral exceptionalism (23), which makes its rightward turn away from refugee hospitality all the more puzzling and troubling. Although it seeks to explain this, it does not provide a satisfying account of why or how the turn happened. A basic yet important premise of the study is that we can understand these dynamics only by examining the everyday. But after describing the history of Sweden's myth of national righteousness, and providing a literature review of other perspectives on Swedish history, the analysis zooms in to examine minor events and petty squabbles: the kind of irritations, misunderstandings, 
competitions, and resentments that characterize village life almost anywhere. This is the kind of material many ethnographers plumb for insights into oppositional politics, but it can only offer real insight when it points to obscured actors, reveals broader patterns, and bespeaks deeper ideologies. From McCluskey we learn that some of the villagers did not like some of the Syrian refugees' complaints about the inadequate help they were given, but where that dynamic of animosity came from or what it led to is not always clear.

Neither the villagers nor the Syrian refugees are adequately fleshed out as people with full biographies, histories, and mixed motivations, nor is the focus on a rural village opened up by situating it in relation to contemporary events in Sweden or elsewhere in Europe. It would have been helpful to understand more about how this example from a small corner of the globe illuminates broader dynamics, how a village in Sweden tells us something about, say, the turning tide of European sentiment against refugees and Muslims, which in this text is more presumed than argued (I7I-72).

McCluskey's ethnographic focus jars when set against her more general observations and sources. When it comes to explaining the deeply moralizing, righteous nature of Swedish nationalism, which constituted a "vague background to everyday life" (66) and is a pivotal element of her analysis - what she terms the "governmentality of righteousness"-she reverts to more traditional political science sources: surveys, opinion polls, and ministerial statements. Scales of analysis are left unintegrated. Was Swedish governmental discourse regarding national solidarity and EU asylum policy (I62-63) felt positively by regular Swedes as manifesting a national character of generosity, and did it feed in to their attitudes towards the Syrians in their midst? Were McCluskey to provide more by way of first-person reaction from the villagers, what they said about Sweden being the "conscience of the world" and "moral superpower" (I29) when such notions were reflected to them as an ideal across a variety of contexts, she might have been able to make more sense of their turning against the refugees-how refugees as a class came to appear to these Swedes as unworthy and ungrateful guests. It is clear that the author is critical of this nationalist myth of Swedish morality, dismissing it as a superficial "public transcript."[iv] But we learn little on an ethnographic level of how the myth has taken hold of so many, and how it can justify both generosity to strangers and suspiciousness towards those thought guilty of milking the system (I3I).

Many of the interesting questions McCluskey poses, such as how "solidarity in its relation 
to violence and security is absolutely critical in enabling the refugees to be legitimately conceptualized as non-deserving" (38), are ultimately left unanswered. McCluskey does mention the media as driving "the moral panic" that made refugees suspect, and she notes that the former head of the NGO supporting the refugees began interacting with antiimmigrant blogs (13I), but she presents no systematic analysis or even description of the media and its makers, nor does she consider whether online media was cause or effect of these attitudes. Still, From Righteousness to Far Right poses tantalizing questions about regular people's attitudes to questions of state security and shifting attitudes toward the immigrants who are portrayed as a threat to that security.

\section{Fear, Space, and Urban Securityscapes}

In his Fear, Space and Urban Planning Simone Tulumello also identifies media as an important cause of the sense of insecurity that drives securitization in the "ordinary cities" of Palermo and Lisbon (two cities chosen to provide a contrast to the global cities that are more often the focus of such research) (20I7, 3I-32). Like

McCluskey, Tulumello observes "a culture of fear," but does not explain who crafted it or why, or how the culture circulated, took root, or guided people's attitudes and actions (25). Also like McCluskey, Tulumello describes the I99os as an important period when "something" happened to make "the west" more afraid (24-25), and still we are left wondering who was involved, why, and why then. McCluskey and Tulumello share a focus on the political power of fear that could provide a more critical understanding of how the public and private discourses which stoke fear are produced, circulated, and made convincing. It deserves a different kind of disciplinary attention, however, sensitive to the interactions among individuals in which fear shapes attitudes and behaviors.

While he records the media's intensified focus on crime reporting (which in the US went up 600\% between 1990 and 1998, as homicide rates went down) (20-2I, 23), Tulumello's main interest is to understand "how political economies of fear have become embedded in the micro-practice of planning policy" (96). Such policies and practices, he posits, have themselves led citizens of Italy and Portugal and elsewhere to believe they are more vulnerable to violence, even as actual crime rates have plummeted since the ig9os. Less ethnographic than the other texts, this book focuses on some of the spatial dimensions of 
urban life that reflect the "insecuritization" observed by many of the works under review.

Tulumello parses the forms of urban organization that construct "Southern European Fearscapes" in urban spaces. These include: enclosure, barrier, post-public space, and control. He cites the archipelago of Israeli settlements and barriers blocking Palestinians' free movement as an example (II7). Barriers come in a variety of forms. Road infrastructures segregate poor suburban districts of Paris, and road and railway lines in Lisbon "splinter the whole urban territory" and allow gated communities "to be connected to the rest of the city without being contaminated by the "marginal" (66). "Post-public space" is the term Tulumello gives to all those devices and policies-such as anti-homeless studs, the privatization of sidewalks in front of stores, and other measures to deter beggars-that reduce public access to certain spaces, and that exclude poor or otherwise "undesirable" populations. CCTV, a form of "voluntary panoptic" (72) is the typical mechanism of his final category, control and surveillance. Together, he argues, these practices "have in common a trend towards the erosion of common rights to the city" (80).

Coming in and out of focus throughout Tulumello's analysis is the socio-economic dimension of how these formulations of space are effective, tailored as they are for retail, tourism, business, and those who can afford to take part in those activities. His analysis of two neighborhoods in Palermo and Lisbon provides some detail about what ring roads and mixed housing can do to exacerbate spatial and social segregation. New planning instruments such as the inclusion of "stakeholders" in decision-making, with "stakes" being defined in ways that exclude already marginalized residents from the conversation, and the "selective non-planning" of marginalized areas painted as dangerous, together help reflect and entrench powerful interests (97-99). It is not clear precisely who those powerful interests are, nor what the mechanisms are by which they influence urban planning. It is asserted, rather than ethnographically demonstrated, that fear drives these segregationist practices.

Nuancing his argument, Tulumello recognizes that fear is produced out of a complex mix of factors, not made or addressed solely by urban planning (I07). Less convincing are the idealistic but vague recommendations for challenging the "politics of fear" that he proffers: listening to different voices, creativity, imagining a different way, discourse to counter fear, and embracing marginality (I20-I23). Tulumello’s most compelling 


\section{suggestion is "to tell the history of insurgency achievements" (I25).}

Shah is the only one among these authors who has explored the sources of an insurgent force that might slow the runaway train of fear-driven securitization. Although tracing resistance to securitization was not a stated goal of their work, this lacuna was still startling in the volume edited by Setha Low and Mark Maguire (2019), Spaces of Security, given its many fine, ethnography-rich contributions by anthropologists, in contexts in which one might have expected to find people refusing the many forms of securitization's violence in their lives. Focused on forms of "spatial governance" (24), the essays in this volume forefront the material infrastructures through which security practices and actors entrench the sense of insecurity that justifies their existence. While all social dynamics have a material dimension, the editors believe there is some urgency to understanding securitization through a spatial lens, to counter-balance what they seem to think has been an over emphasis on its ideological and discursive aspects (5).

Perhaps because of the focus on the spatial dimensions of social life, the essays provide a very uneven sense of how people define security, experience (in)security, and how they make sense of it or become oblivious to its senselessness. The collection's focus on material aspects of security may have tipped the balance too far away from a consideration of the ideological, leaving the significance and meanings of security underspecified. One exception, in contrast to the editors' vague glossing of security as a dangerous, "rascal concept," (I, 2I), is Katherine Verdery's contribution to this volume. She discusses histories of security and tackles the definitional problem as one might expect an anthropologist to do, by understanding what actors on the ground mean by the term and recognizing its ideological uses. Starting with the Soviet notion of security "as the opposite of poverty and exploitation," Verdery explains the kinds of state actions that were then justified in the name of increasing the well-being of the poor (6I). By way of contrast, this highlights sharply how far the well-being of the poor is from most of today's security concerns.

Many of the other essays in this volume convey well the absurdity of people's private attempts to reach an always vague and unachievable sense of security. Thomas Kirsch's chapter on "securing security" in South Africa describes the never-ending quest for an ultimate security. Like some dark children's fable, the craze for security leads homeowners 
to purchase ever more technologies - a guard dog, a fence to secure the guard-dog, a camera to survey the fenced-in area that houses the dog, ad absurdam (I22-I40). Also highlighting the farcical nature of state security, Zoltan Gluck's excellent essay on counterterrorism in Kenya gives insight into the anti-immigrant and classed nature of state security in that country, such that a well-dressed man could pass through airport security carrying weapons simply because he looked rich.

Most of the contributions to this volume describe the elite and middle-class "anxious subjects" who inhabit securitized spaces while remaining fearful of "dangerous others" (46), and observe the irony that these spaces themselves contribute to people's sense that they have a lot to fear. So-called gated communities in the US, checkpoints at Nairobi malls, and bunkered rooms in Israeli houses keep people feeling that the next criminal infiltration or terrorist attack is right around the corner. Curiously absent from most of this volume is an analysis of whether these anxious subjects understand why they are under constant threat of assault-and if their lack of questioning sustains a status-quo of inequality. It is obvious in these accounts that the security being sought by states and the elite is only their security, not that of refugees, the poor, those fighting for equality and liberation. The work of Tulumello and Maguire and Low's volume both demonstrate that racist and classist ideologies drive and justify securitization and are instantiated in material, sometimes infrastructural form. But absent a consideration of who is benefiting from security regimes, and who is being hoodwinked by them, the political critique of these volumes is not as sharp as it could have been.

\section{CONCLUSION}

Consideration of these texts together reveals how much might be gained from a greater cross-disciplinary conversation between Anthropology and Critical Security Studies. Anthropological analysis might benefit from heightened attention to the political economy of security regimes, including an attention to those who produce and profit from the material infrastructures of security. Tracing more exactly who the beneficiaries of the business of security actually are might reveal more plainly the anti-poor ideologies that fuel the self-centered aspiration for absolute domestic safety that besets "anxious subjects" in many contexts. Across all disciplines interested in the new forms of securitization that are stifling lives and atomizing societies, scholars should consider how 
to balance attentiveness to the lived experiences of insecurity-to the paranoia and fear bred by securitization processes and the absurd, never-ending quest for a security that can never be available in such a deeply unequal world-with analysis of how some people manage to reject and resist the security ideology. When they do resist, as the Naxalites have done, it is often because they possess a critique of the world that has made some so privileged that they become relentlessly anxious subjects, desperate enough to protect themselves by holing up in bunkers and behind gates, peering through surveillance cameras and gun barrels. Perhaps this scholarship could learn from the insights of those insurgents, and contribute to building that critique which names the raced and classed privilege driving the insecuritization of all our lives.

\section{References Cited}

Abboud, Samer, Omar S. Dahi, Waleed Hazbun, Nicole Sunday Grove, Coralie Pison Hindawi, Jamil Mouawad \& Sami Hermez. 2018. "Towards a Beirut School of Critical Security Studies." Critical Studies on Security 6(3): 273-295.

ACLU. N.d. "ICE and Border Patrol Abuses." Accessed September 3, 2019.

https://www.aclu.org/issues/immigrants-rights/ice-and-border-patrol-abuses.

Crivelentem, Moara. 20I6. "Deporting Solidarity." Accessed September 3, 2019. https://www.alhaq.org/advocacy/6396.html.

Barkawi Tarak and Mark Laffey. 2006. "The Postcolonial Moment in Security Studies.” Review of International Studies 32: 329-352.

BBC. 2016. “New 'Ring of Steel' Planned for London Square Mile,” December 24. Accessed September 3, 20I9. https://www.bbc.co.uk/news/uk-england-london-384I8877.

BBC. 20I9. "Donald Trump UK Visit: All You Need to Know." June 4. Accessed September 3, 20I9. https://www.bbc.co.uk/news/uk-38794886

B'Tselem. 20I7. "Israel Bars Thousands of Palestinians from Traveling Abroad; Many Other Don't Even Bother to Make the Attempt." May I7. Accessed September 3, 2019. https://www.btselem.org/freedom_of_movement/201705I5_thousands_of_palestinians_b 


\section{arred_from_traveling_abroad.}

C.A.S.E. Collective. 2006. "Critical Approaches to Security in Europe: A Networked Manifesto." Security Dialogue 37(4) :443-487.

Gluck, Zoltan. 2019. "Security Urbanism and the Counterterror State in Kenya." In Spaces of Security: Ethnographies of Securityscapes, Surveillance, and Control, edited by Setha Low and Mark Maguire, 3I-56. New York: New York University Press.

Howell, Alison and Melanie Richter-Montpetit. 2019. "Is Securitization Theory Racist? Civilizationism, Methodological Whiteness and Antiblack Thought in the Copenhagen School." Security Dialogue OnlineFirst (Aug 7): https://doi.org/Io.II77/o9670106I986292I

Human Rights Watch. 2018. "India: Dalit Rights Activists Detained.” June 24. Accessed September 3, 2019. https://www.hrw.org/news/2018/06/24/india-dalit-rights-activistsdetained

Hynek, Nik and David Chandler. 20I3. "No Emancipatory Alternative, No Critical Security Studies." Critical Studies on Security I(I): 46-63.

Kirsch, Thomas G. 2019. "Securing Security: Recursive Security Assemblages in South Africa." In Spaces of Security: Ethnographies of Securityscapes, Surveillance, and Control, edited by Setha Low and Mark Maguire, I22-I40. New York: New York University Press.

Maguire, Mark and Setha Low. 20I9. "Introduction: Exploring Spaces of Security." In Spaces of Security: Ethnographies of Securityscapes, Surveillance, and Control, edited by Setha Low and Mark Maguire, I-30. New York: New York University Press.

McCluskey, Emma. 20I9. From Righteousness to Far Right: An Anthropological Rethinking of Critical Security Studies. Montreal \& Kingston: McGill-Queen's University Press.

Rial, Carmen. 2019. "From Panopticon to Panasonic: The Architecture of Fear in MegaEvents." In Spaces of Security: Ethnographies of Securityscapes, Surveillance, and Control, edited by Setha Low and Mark Maguire, 99-I2I. New York: New York University Press. 
Shah, Alpa. 2018. Nightmarch: Among India's Revolutionary Guerrillas. London: Hurst \& Company.

Scott, James C. 1990. Domination and the Arts of Resistance: Hidden Transcripts. New Haven: Yale University Press.

Tulumello, Simone. 2017. Fear, Space and Urban Planning: A Critical Perspective from Southern Europe. Springer International Publishing Switzerland.

Verdery, Katherine. 2019. "Comparative Surveillance Regimes: A Preliminary Essay." In Spaces of Security: Ethnographies of Securityscapes, Surveillance, and Control, edited by Setha Low and Mark Maguire, 57-77. New York: New York University Press.

Wæver, Ole. 2004. "Aberystwyth, Paris, Copenhagen: New 'Schools' in Security Theory and Their Origins Between Core and Periphery." Presentation at Annual Meeting of the International Studies Association, Montreal, March I7-20.

[i] The 'ring of steel' protection for US President Donald Trump during his 2019 UK visit was estimated to have cost $€ \mathrm{I} 8$ million (BBC 20I9).

[ii] See Wæver 2004, C.A.S.E. Collective 2006, Abboud, et al., 2018.

[iii] For a critique of the Eurocentrism that characterised security studies that developed after World War II, see Barkawy and Laffey 2006.

[iv] This is framed by a strange and not altogether clarifying transfiguration of James Scott's concept, which was originally meant to capture the necessary dissimulations that inferior groups cultivate throughout "the open interaction between subordinates and those who dominate" in order to get by (Scott 1990, 2-3).

\section{Tagged:}

Political \& Legal Anthropology on Twitter 
SALSA Open Letter on Brazilian Fires

Graduate Student Workshops at AAAs

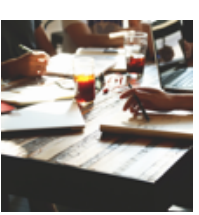

APlA at the AAAs: Early Career Mentoring

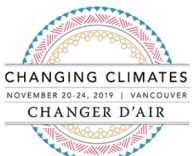

APLA SUPPORTS TURKISH SCHOLARS

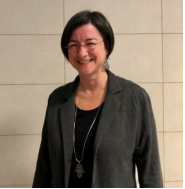

Stay up to date!

Enter your email address to follow us and receive notifications about new articles and features. 
You and 31 other friends like this

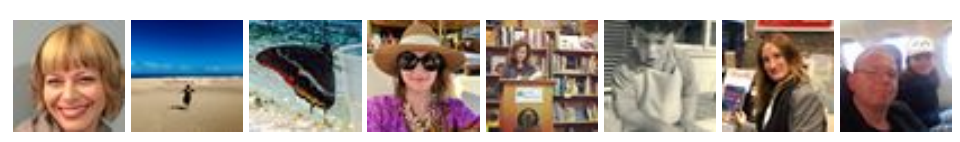

PoLAR

\section{Political and Legal Anthropology}

Review

on Friday

“Jeffrey Kahn's Islands of Sovereignty is a powerful and sophisticated ethnography of the political and legal system at the heart of the United States government's policy of interdicting Haitian refugees and migrants at sea."

Read Greg Beckett's review, now in PoLAR! https://polarjournal.org/2019/09/26/islands-ofsovereignty/

\section{ISLANDS OF SOVEREIGNTY}

POLARJOURNAL.ORG

Islands of Sover...

by Greg Beckett, W... 